University of Nebraska - Lincoln

DigitalCommons@University of Nebraska - Lincoln

7-2-2007

\title{
Bovine respiratory disease in feedlot cattle: Phenotypic, environmental, and genetic correlations with growth, carcass, and longissimus muscle palatability traits
}

\author{
G. D. Snowder \\ USDA-ARS \\ L. Dale Van Vleck \\ University of Nebraska-Lincoln, dvan-vleck1@unl.edu \\ L. V. Cundiff \\ USDA-ARS \\ G. L. Bennett \\ USDA-ARS, gary.bennett@ars.usda.gov \\ M. Koohmaraie \\ USDA-ARS
}

See next page for additional authors

Follow this and additional works at: https://digitalcommons.unl.edu/animalscifacpub

Part of the Animal Sciences Commons

Snowder, G. D.; Van Vleck, L. Dale; Cundiff, L. V.; Bennett, G. L.; Koohmaraie, M.; and Dikeman, M. E., "Bovine respiratory disease in feedlot cattle: Phenotypic, environmental, and genetic correlations with growth, carcass, and longissimus muscle palatability traits" (2007). Faculty Papers and Publications in Animal Science. 122.

https://digitalcommons.unl.edu/animalscifacpub/122

This Article is brought to you for free and open access by the Animal Science Department at DigitalCommons@University of Nebraska - Lincoln. It has been accepted for inclusion in Faculty Papers and Publications in Animal Science by an authorized administrator of DigitalCommons@University of Nebraska - Lincoln. 


\section{Authors}

G. D. Snowder, L. Dale Van Vleck, L. V. Cundiff, G. L. Bennett, M. Koohmaraie, and M. E. Dikeman 


\title{
Bovine respiratory disease in feedlot cattle: Phenotypic, environmental, and genetic correlations with growth, carcass, and longissimus muscle palatability traits ${ }^{1}$
}

\author{
G. D. Snowder, ${ }^{2}$ L. D. Van Vleck, $\dagger$ L. V. Cundiff, * G. L. Bennett, $*$ \\ M. Koohmaraie, $*$ and M. E. Dikeman $*$ \\ *US Meat Animal Research Center, ARS, USDA, Clay Center, NE 68933; †US Meat Animal Research Center, \\ ARS, USDA, Lincoln, NE 68583; and $\ddagger$ Department of Animal Sciences and Industry, \\ Kansas State University, Manhattan 66506
}

\begin{abstract}
Bovine respiratory disease (BRD) is the most costly feedlot disease in the United States. Selection for disease resistance is one of several possible interventions to prevent or reduce the economic loss associated with animal disease and to improve animal welfare. Undesirable genetic relationships, however, may exist between production and disease resistance traits. The objectives of this study were to estimate the phenotypic, environmental, and genetic correlations of BRD with growth, carcass, and LM palatability traits. Health records on 18,112 feedlot cattle over a 15 -yr period and slaughter data on 1,627 steers over a 4-yr period were analyzed with bivariate animal models. Traits included ADG, adjusted carcass fat thickness at the 12th rib, marbling score, LM area, weight of retail cuts, weight of fat trim, bone weight, Warner-Bratzler shear force, tenderness score, and juiciness score. The
\end{abstract}

estimated heritability of BRD incidence was $0.08 \pm 0.01$. Phenotypic, environmental, and genetic correlations of the observed traits with $\mathrm{BRD}$ ranged from -0.35 to $0.40,-0.36$ to 0.55 , and -0.42 to 0.20 , respectively. Most correlations were low or negligible. The percentage of carcass bone had moderate genetic, phenotypic, and environmental correlations with BRD $(-0.42,-0.35$, and -0.36 , respectively). Hot carcass weight and weight of retail cuts had moderate, undesirable phenotypic correlations with $\mathrm{BRD}(0.37$ and 0.40 , respectively). Correlations of BRD with LM palatability and ADG were not detected. Low or near zero estimates of genetic correlations infer that selection to reduce BRD in feedlot cattle would have negligible correlated responses on growth, carcass, and meat palatability traits or that selection for those traits will have little effect on BRD susceptibility or resistance.

Key words: beef cattle, carcass trait, health, performance, selection, shipping fever

(C2007 American Society of Animal Science. All rights reserved.

J. Anim. Sci. 2007. 85:1885-1892

doi:10.2527/jas.2007-0008

\section{INTRODUCTION}

Bovine respiratory disease (BRD) is the most costly beef cattle disease in the United States. Costs associated with BRD prevention, treatment, morbidity, and mortality have been estimated from $\$ 13.90$ (Snowder et al., 2006) to $\$ 15.57$ (Faber et al., 1999) per head. Annual losses to the US cattle industry are estimated to approach $\$ 1$ billion, whereas preventative and treatment costs are over $\$ 3$ billion annually (Griffin, 1997).

\footnotetext{
${ }^{1}$ Mention of trade name, proprietary product, or specified equipment does not constitute a guarantee or warranty by the USDA and does not imply approval to the exclusion of other products that may be suitable.

${ }^{2}$ Corresponding author: Gary.Snowder@ars.usda.gov

Received January 3, 2007.

Accepted April 30, 2007.
}

Selection for disease resistance is one of several alternatives to prevent or reduce economic losses associated with animal disease and to improve animal welfare. Undesirable genetic relationships, however, sometimes exist between production and health traits (Rauw et al., 1998). Selection for increased growth rate depressed immune performance (Miller et al., 1992) and increased mortality in broilers (Leenstra, 1993) and turkeys (Nestor et al., 1996). Selection for percentage of carcass lean in pigs increased leg weaknesses (Sather, 1987). In dairy cattle, milk yield has undesirable genetic correlations with mastitis, ketosis, and disease records (Simianer et al., 1991) and with cystic ovaries and metritis (Van Dorp et al., 1998). In sheep, selection against the prion protein gene associated with scrapie susceptibility decreased lamb weights (Brandsma et al., 2004); however, Isler et al. (2006) reported no significant or important genetic association of the prion protein gene 
Table 1. Number of feedlot cattle and steers slaughtered and years recorded by breed type

\begin{tabular}{lrcc}
\hline Breed type & $\begin{array}{c}\text { Feedlot } \\
\text { cattle }\end{array}$ & $\begin{array}{c}\text { Slaughter } \\
\text { steers }\end{array}$ & Years \\
\hline Angus & 2,127 & 118 & 1987 to 2001 \\
Hereford & 1,649 & 145 & 1987 to 1999 \\
Charolais & 1,883 & 121 & 1987 to 2001 \\
Gelbvieh & 1,649 & 146 & 1987 to 2001 \\
Red Poll & 387 & 101 & 1987 to 1991 \\
Simmental & 355 & 120 & 1987 to 1991 \\
Pinzgauer & 346 & 113 & 1987 to 1991 \\
Braunvieh & 380 & 134 & 1987 to 1991 \\
Limousin & 436 & 140 & 1987 to 1991 \\
MARC I & 2,974 & 175 & 1987 to 2001 \\
MARC II & 2,962 & 146 & 1987 to 2001 \\
MARC III & 2,964 & 155 & 1987 to 2001 \\
Overall & 18,112 & 1,627 & \\
\hline
\end{tabular}

with 25 growth, carcass, and meat quality traits. Selection to reduce fecal parasitic egg count (indirect selection for resistance to internal parasites) increased backfat depth in lambs (Pollott and Greef, 2004).

Phenotypic and genetic relationships between production and health traits in beef cattle have not been clearly established. Before incorporating health traits into selection indices, potential genetic antagonisms between production and health traits must be understood.

Therefore, the objectives of this study were to estimate the phenotypic and genetic correlations of BRD with growth, carcass, and meat palatability traits.

\section{MATERIALS AND METHODS}

\section{Animals}

All experimental procedures were reviewed and accepted by the ARS Animal Care and Use Committee and were in accordance with the Federation of Animal Science Society's Guide to Care and Use of Agricultural Animals in Agricultural Research and Teaching. Growth data $(\mathrm{n}=18,112)$, health records $(\mathrm{n}=18,112)$, and carcass data $(n=1,627)$ of cattle in feedlots at the US Meat Animal Research Center (USMARC), Clay Center, Nebraska, for a 15-yr period (1987 through 2001) were evaluated (Table 1). The data were for 9 pure breeds (Angus, Braunvieh, Charolais, Gelbvieh, Hereford, Limousin, Pinzgauer, Red Poll, and Simmental) and 3 composite breeds (MARC I, MARC II, and MARC III).

Not all 12 breeds were represented across all years. Five breeds (Braunvieh, Pinzgauer, Red Poll, Simmental, and Limousin) had records only from 1987 through 1991. Hereford records were available from 1987 through 1999. Breeds present across all years included Angus, Charolais, Gelbvieh, and the 3 MARC composites.

Calves were typically born over an average period of $101 \mathrm{~d}$ between mid-February and early June. Only single-birth and spring-born calves were considered.
Preweaning management, pasture description, and supplemental feeding of the cows and calves have been previously described by Gregory et al. (1991) and Snowder et al. (2006).

\section{Management and Environment}

Feeding and management in the feedlot were previously described by Gregory et al. (1994a,b). Cattle were begun on a backgrounding diet of $2.65 \mathrm{Mcal}$ of $\mathrm{ME} / \mathrm{kg}$ of DM with $15.4 \% \mathrm{CP}$ on a DM basis. Steers were randomly assigned to 1 of 2 finishing diets. Finishing diet 1 contained $2.83 \mathrm{Mcal}$ of $\mathrm{ME} / \mathrm{kg}$ of $\mathrm{DM}$ and $11.5 \% \mathrm{CP}$ on a DM basis. Finishing diet 2 contained $3.07 \mathrm{Mcal}$ of $\mathrm{ME} / \mathrm{kg}$ of $\mathrm{DM}$ and $11.5 \% \mathrm{CP}$ on a $\mathrm{DM}$ basis. On average, across years, the cattle were fed the backgrounding diet for approximately $5 \mathrm{wk}$ to become adjusted to the finishing diet. The average feeding period was $200 \mathrm{~d}$, with an $\mathrm{ADG}$ of $1.0 \mathrm{~kg}$ for all steers and heifers. Breed effects on growth and the efficiency of gain estimated from this data set have been previously reported (Gregory et al., 1994a,b, 1995; Rios-Utrera et al., 2005).

Calves entered the feedlot at an average age of 176 $\mathrm{d}$ and BW of $205 \mathrm{~kg}$. Protocols for vaccination and treatment of sick cattle were described by Snowder et al. (2006). Calves were fed separately by sex and were generally fed within breed groups. Pens were of 2 sizes, $15 \times 61 \mathrm{~m}\left(915 \mathrm{~m}^{2}\right)$ and $29 \times 61 \mathrm{~m}\left(1,769 \mathrm{~m}^{2}\right)$. Steers were stratified according to live BW to pens in initial groups of 24 cattle. Heifers were generally fed in the larger pens in multiple breed groups with more cattle per pen. The number of calves per pen ranged from 6 to 72 over the feeding period.

\section{Growth and Carcass Traits}

Growth rate was defined as ADG during the time on feed. Carcass and LM palatability data were collected on steers representing all 12 breed types $(n=1,627)$ only from 1988 through 1991. Steers were serially slaughtered at 4 d-on-feed end points with 20,21 , or $22 \mathrm{~d}$ between slaughter dates. Steers within a breed were assigned to a slaughter group on a random basis, stratified by BW based on the last BW taken before the beginning of the serial slaughter schedule (Gregory et al., 1994c). Slaughtered steers were fed for a mean of $235 \mathrm{~d}$, with a mean age at slaughter of approximately $440 \mathrm{~d}$. No heifers were slaughtered. Carcasses were processed into wholesale cuts, which were further processed into boneless steaks, roasts, and lean trim.

Carcass traits included adjusted s.c. fat at the 12th rib, marbling score, area of LM, KPH, retail product weight and percentage, fat trim weight and percentage, chemical fat percentage in wholesale rib soft tissue, chemical fat in LM, and bone weight and percentage. After a 24-h chill period, measurements of s.c. fat thickness at the 12th rib visually adjusted for variations in distribution on the carcass, area of the LM, and mar- 
bling score were taken. Retail product included trimmed steaks and roasts plus lean trim adjusted to $20 \%$ fat. Fat trim included all s.c. and accessible intermuscular fat removed during fabrication of the wholesale and related retail cuts. Palatability traits included Warner-Bratzler shear force of the LM and trained sensory panel scores for tenderness and juiciness. WarnerBratzler shear force was measured on 1.27-cm-thick LM steaks from the 5 th to the 6 th rib. Data collection procedures, as well as estimates of breed effects for growth, efficiency of gain, carcass, and meat sensory traits, have been previously reported (Gregory et al., 1994a,b, 1995).

\section{Period Effect}

The effect of BRD on growth rate can be influenced by the period when the BRD illness in the feedlot occurred (Bateman et al., 1990; Faber et al., 1999). Thus, the effect of period when the BRD treatment occurred on carcass and LM palatability traits was examined by adding to the model a group effect for period when the BRD treatment occurred. Cattle with BRD treatment records were assigned to 1 of 3 period-when-treated groups: EARLY (1 through 40 d), MID (41 through 80 d), and LATE (81 d or greater). Classification was based on the epidemiological curve for BRD treatment reported by Snowder et al. (2006), in which incidence of BRD peaked at d 14 on feed and remained high until approximately d 80 on feed, followed by a decrease in incidence until it was negligible at about $110 \mathrm{~d}$ on feed. Although this classification resulted in unbalanced group sizes of approximately 200 (EARLY), 300 (MID), and 100 (LATE) cattle, the contagious period of 1 through $80 \mathrm{~d}$ was separated into 2 equal time stages, whereas the LATE stage covered approximately $120 \mathrm{~d}$. Cattle with no BRD treatment records were assigned to the HEALTHY group ( $\mathrm{n}=$ approximately 1,000$)$.

\section{Disease Detection}

Cattle were monitored daily by the staff veterinarian, beef cattle research technicians, or both. Diseases were detected by physical examination, necropsy, or laboratory analyses and were recorded. Typical clinical symptoms for BRD included one or more of the following: fever, rapid breathing, repetitive coughing, nasal or eye discharge or both, diarrhea, dehydration, and appetite depression. Disease classifications related to BRD were combined. The majority of the classifications for BRD were from classifications for pneumonia and respiratory disease (86 and 11\%, respectively). Additional disease classifications included for BRD were bronchitis, emphysema, pleuritis, pulmonary adenomatosis, upper respiratory infection, and pleural fibrosis. Because such diseases may be interpreted as BRD by feedlot staff, it seemed appropriate to include them as BRD in the data set. The recoded binary classification listed cattle as either not treated (classification $=200$ ) or treated for BRD $($ classification $=100)$.

\section{Statistical Procedures}

Statistical analyses were performed using the computer programs of Boldman et al. (1995) using a derivative-free REML algorithm (Graser et al., 1987). Linear models for growth, carcass, and LM palatability traits were similar. Fixed effects included breed $(\mathrm{n}=12)$, year of birth (1988 through 1991 for carcass and LM palatability traits; 1987 through 2001 for growth), finishing diet (1 or 2), and group (EARLY, MID, LATE, HEALTHY). Age at weaning and number of days on feed were included as covariates. With the exception of group, the statistical models were similar to those used in previous analyses of these traits (Gregory et al., 1994a,b, 1995).

The effects of BRD and period when treated for BRD on carcass and LM palatability traits were evaluated by linear contrasts of the solutions for the HEALTHY group with the solutions for the groups treated for BRD. The effects of period when treated for BRD on the various traits were determined by linear contrasts for solutions for groups treated for BRD (EARLY, MID, LATE). The general effect of BRD on the various traits was determined by contrasts of weighted solutions for groups treated for BRD with the HEALTHY group. A Student's $t$-test, with a level of significance of 0.05 was used for each contrast.

Variance Components. Variance components and genetic correlations were estimated using data from all purebred and composite breeds combined in an overall analysis. The pedigree file used to calculate the relationship matrix consisted of 47,880 cattle born from 1972 through 2001, including 1,655 sires and 15,648 dams. The number of cattle in the pedigree file with a nonzero inbreeding coefficient was 6,984 . Those cattle had an average inbreeding coefficient of $2.3 \%$. Of the 18,112 feedlot cattle, 5,104 had nonzero inbreeding coefficients, with an average of $2.2 \%$. The effect of inbreeding on growth and carcass traits and on BRD incidence was assumed to be negligible.

Variance components for each trait were initially estimated using a single-trait animal model. Convergence was considered to have been reached when the variance of the $-2 \log \mathrm{L}$ in the simplex was less than $1 \times 10^{-6}$. After the initial convergence, 4 restarts were performed to ensure global convergence, as determined when the $-2 \operatorname{logL}$ did not change to the second decimal. Standard errors of the heritability estimates were based on the average information matrix and the delta method (Dodenhoff et al., 1998).

The model for analyses of BRD score included fixed effects for year, breed type, and sex of calf and 2 linear covariates (initial BW on entering the feedlot and total days on feed). Calf (genetic direct) was a random effect. Because breed types were confounded with years, and the incidence of BRD varied with groups of years, breed type by year was regarded as an uncorrelated random effect. Estimates with this model for BRD score were previously reported by Snowder et al. (2006). 
Genetic correlations for BRD with growth, carcass, and LM palatability traits were estimated with bivariate analyses, using models previously described. Because not all cattle were slaughtered, SE of the genetic correlations were estimated using a procedure that nests each missing observation within a unique level of a dummy fixed factor associated with each trait (S. D. Kachman, University of Nebraska, Lincoln and L. D. Van Vleck, personal communication). Phenotypic correlations were derived by dividing the sum of the genetic and environmental covariances by the product of the estimates of the phenotypic SD (Falconer, 1976).

\section{RESULTS AND DISCUSSION}

The average annual incidence of BRD across all years (1987 to 2001), including heifers and steers, was approximately $17 \%$. However, the average annual incidence of BRD was much greater from 1988 through 1991 when steers were slaughtered for carcass and LM palatability data. In a previous study of these data, Snowder et al. (2006) reported annual incidences of BRD ranging from 5 to $44 \%$ per year, with greater incidences occurring from 1987 through 1992. Incidence rates of epidemic proportions were observed in 1990 (44\%) and 1991 (33\%). The greater incidence rates were attributed to factors related to year and management effects rather than to sampling. These factors included the use of less effective killed virus vaccines from 1987 through 1992 compared with modified live virus vaccines used from 1993 through 2001, adding parainfluenza-3 vaccine to the calf vaccination program in 1995 , and changing the castration method from surgical (1987 through 1989) to mechanical banding (1990 through 2001). After 1992, the annual overall incidence remained less than $14 \%$, although there were occasional high incidence rates for some breed types. Breed differences for susceptibility to BRD were presented earlier by Snowder et al. (2006).

The use of clinical signs or treatment records for classifying BRD may have limitations. Subclinically infected animals are not classified. At slaughter, the presence of lung lesions is a common method of determining current or previous respiratory lung infection. Not all cattle with lung lesions associated with BRD will have clinical symptoms, and not all cattle with BRD symptoms will have detectable lung lesions at slaughter (Wittum et al., 1996; Gardner et al., 1999). Subclinical respiratory tract infections may produce permanent lung damage and have associated negative effects on growth and carcass traits. Gardner et al. (1999), however, reported that differences in growth and carcass traits between treated and nontreated steers and between steers with or without lung lesions were generally similar.

Unadjusted means and SD for growth, carcass, and LM palatability traits are reported in Table 2 and are similar to those reported by Gregory et al. (1995), using an almost identical data set. Because data from heifers were included in this study, the mean for ADG is less than that previously reported by Gregory et al. (1995). Effects of breed and retained heterosis for these traits have been previously reported (Gregory et al., 1994a,b). Cattle treated for BRD had somewhat smaller means and SD for fat-related traits than the HEALTHY group.

Unadjusted means and numbers for period-whentreated groups are reported in Table 3. Although the period for the LATE group included $120 \mathrm{~d}$ of the 200$\mathrm{d}$ feeding period, the number of cattle treated for BRD was much less than the numbers in the EARLY and MID groups. Unadjusted means were generally not significantly different among groups treated for BRD within a trait. However, cattle treated during the LATE period tended to have heavier carcasses, more retail product, less fat trim, and heavier bone weight than EARLY and MID groups.

Linear contrasts also identified significant reductions (Table 4) in most carcass fat traits of BRD-treated cattle compared with healthy cattle. These traits included adjusted 12th rib carcass fat, KPH fat percentage, and fat trim weight and percentage. Decreases in external and internal measures of fat due to BRD have been previously reported (Gardner et al., 1999; Roeber et al., 2001). The effect of BRD on marbling score was not significant and agrees with a study by Gardner et al. (1999); however, significant decreases in marbling score for BRD-treated cattle have been reported (Roeber et al., 2001).

Illness due to BRD was also associated with decreased carcass weight, which, in turn, decreased weight and percentage of retail product $(P \leq 0.05$; Table 4). Lighter carcass weights due to BRD were previously reported by Gardner et al. (1999) and Roeber et al. (2001). The increase in percentage of bone in BRDinfected calves was likely related to lighter carcass weights as a result of decreased fat. Calves treated for BRD did not differ from healthy calves for $\mathrm{ADG}$, marbling score, percentage of fat in the rib soft tissue and LM, and LM palatability traits.

Previous studies have reported that cattle with BRD generally have less ADG when compared with healthy animals (Bateman et al., 1990; Gardner et al., 1999; Snowder et al., 2006). In this study, we used the same data set used by Snowder et al. (2006), but this time a significant negative effect of $\mathrm{BRD}$ on $\mathrm{ADG}$ was not found. Including the fixed effects of period when treated for BRD in the statistical model in this study is the probable cause for reducing the detectable effect of BRD on ADG. Other researchers have reported nonsignificant differences for ADG between calves treated and not treated for BRD (Jim et al., 1993; Wittum et al., 1996). Faber et al. (1999) reported that after cattle were effectively treated for BRD, compensatory gain was sufficient such that no difference in ADG was observed over a 220-d feeding period. Compensatory gain by BRD-affected calves was also inferred by Bateman et al. (1990), who reported that ADG of BRD-affected calves was $0.14 \mathrm{~kg}$ less than that of healthy calves after 
Table 2. Number of calves and unadjusted means $( \pm \mathrm{SD})$ for growth, carcass, and LM palatability traits by health classification ${ }^{1}$ and overall

\begin{tabular}{|c|c|c|c|c|c|c|}
\hline \multirow[b]{2}{*}{ Trait $^{2}$} & \multicolumn{2}{|c|}{ HEALTHY } & \multicolumn{2}{|c|}{$\mathrm{BRD}$} & \multicolumn{2}{|c|}{ Overall } \\
\hline & $\begin{array}{l}\text { No. of } \\
\text { calves }\end{array}$ & Mean & $\begin{array}{l}\text { No. of } \\
\text { calves }\end{array}$ & Mean & $\begin{array}{l}\text { No. of } \\
\text { calves }\end{array}$ & Mean \\
\hline $\mathrm{ADG}, \mathrm{kg}$ & 14,970 & $1.00 \pm 0.30$ & 2,966 & $1.02 \pm 0.30$ & 17,936 & $1.00 \pm 0.30$ \\
\hline $\mathrm{HCW}, \mathrm{kg}$ & 1,014 & $337 \pm 40$ & 612 & $330 \pm 41$ & 1,626 & $334 \pm 40$ \\
\hline Adjusted carcass fat, $\mathrm{cm}$ & 1,014 & $0.68 \pm 0.45$ & 612 & $0.63 \pm 0.43$ & 1,626 & $0.66 \pm 0.45$ \\
\hline Marbling score & 1,015 & $499 \pm 70$ & 612 & $490 \pm 71$ & 1,627 & $495 \pm 71$ \\
\hline $\mathrm{REA}, \mathrm{cm}^{2}$ & 1,015 & $79.0 \pm 10.5$ & 611 & $78.0 \pm 10.3$ & 1,626 & $78.7 \pm 10.4$ \\
\hline $\mathrm{KPH}$ fat, $\%$ & 1,015 & $2.8 \pm 0.7$ & 612 & $2.7 \pm 0.7$ & 1,627 & $2.8 \pm 0.7$ \\
\hline Retail product, kg & 980 & $211 \pm 28$ & 585 & $208 \pm 28$ & 1,565 & $210 \pm 28$ \\
\hline Retail product, $\%$ & 980 & $65.8 \pm 5.2$ & 585 & $66.3 \pm 5.2$ & 1,565 & $66.0 \pm 5.2$ \\
\hline Fat trim wt, kg & 980 & $61.7 \pm 21.9$ & 585 & $57.6 \pm 21.1$ & 1,565 & $60.1 \pm 21.7$ \\
\hline Fat trim, $\%$ & 980 & $19.1 \pm 6.0$ & 585 & $18.3 \pm 6.0$ & 1,565 & $18.8 \pm 6.0$ \\
\hline Fat in ribs, $\%$ & 980 & $33.2 \pm 7.5$ & 587 & $32.9 \pm 7.6$ & 1,567 & $33.1 \pm 7.6$ \\
\hline Fat in LM palat, $\%$ & 980 & $4.0 \pm 1.4$ & 588 & $3.8 \pm 1.3$ & 1,568 & $3.9 \pm 1.3$ \\
\hline Bone wt, $\mathrm{kg}$ & 981 & $48.3 \pm 6.2$ & 585 & $48.2 \pm 6.7$ & 1,569 & $48.3 \pm 6.4$ \\
\hline Bone, $\%$ & 980 & $15.1 \pm 1.4$ & 585 & $15.4 \pm 1.5$ & 1,565 & $15.2 \pm 1.4$ \\
\hline Shear force, kg & 981 & $5.1 \pm 1.2$ & 588 & $5.2 \pm 1.3$ & 1,569 & $5.2 \pm 1.3$ \\
\hline Tenderness score & 981 & $5.0 \pm 0.7$ & 588 & $5.0 \pm 0.7$ & 1,569 & $5.0 \pm 0.7$ \\
\hline Juiciness score & 981 & $5.2 \pm 0.5$ & 588 & $5.2 \pm 0.5$ & 1,569 & $5.2 \pm 0.5$ \\
\hline Flavor score & 981 & $4.9 \pm 0.4$ & 588 & $4.9 \pm 0.4$ & 1,569 & $4.9 \pm 0.4$ \\
\hline
\end{tabular}

${ }^{1} \mathrm{HEALTHY}=$ not treated for respiratory disease; $\mathrm{BRD}=$ treated for respiratory disease.

${ }^{2}$ Adjusted carcass fat $=$ fat depth at 12 th rib; marbling score, 4.0 to $4.9=$ slight and 5.0 to $5.9=$ small; $\mathrm{REA}=\mathrm{LM}$ area; KPH fat = estimated $\mathrm{KPH}$; retail product = trimmed steaks and roasts; fat in ribs = chemical fat from soft tissue of 9th to 11th rib cut; fat in LM palat = chemical fat in muscle; shear force = Warner-Bratzler force required to cut through a 1.27-cm core of LM; tenderness score, $4=$ slightly tough, $5=$ slightly tender, and $8=$ extremely tender; juiciness score, $4=$ slightly dry, $5=$ slightly juicy, and $8=$ extremely juicy; flavor score, $4=$ slightly bland, $5=$ slightly intense, and $8=$ extremely intense.

Table 3. Number of calves and unadjusted means $( \pm \mathrm{SD})$ for growth, carcass, and LM palatability traits of calves treated for bovine respiratory disease by days-on-feed-whentreated group ${ }^{1}$

\begin{tabular}{|c|c|c|c|c|c|c|}
\hline \multirow[b]{2}{*}{ Trait $^{2}$} & \multicolumn{2}{|c|}{ EARLY } & \multicolumn{2}{|c|}{ MID } & \multicolumn{2}{|c|}{ LATE } \\
\hline & $\begin{array}{l}\text { No. of } \\
\text { calves }\end{array}$ & Mean & $\begin{array}{l}\text { No. of } \\
\text { calves }\end{array}$ & Mean & $\begin{array}{l}\text { No. of } \\
\text { calves }\end{array}$ & Mean \\
\hline $\mathrm{ADG}, \mathrm{kg}$ & 1,724 & $0.98 \pm 0.30$ & 914 & $1.08 \pm 0.29$ & 440 & $1.05 \pm 0.32$ \\
\hline $\mathrm{HCW}, \mathrm{kg}$ & 217 & $327 \pm 41$ & 304 & $330 \pm 42$ & 91 & $339 \pm 37$ \\
\hline Adjusted carcass fat, $\mathrm{cm}$ & 217 & $0.60 \pm 0.41$ & 304 & $0.67 \pm 0.45$ & 91 & $0.56 \pm 0.43$ \\
\hline Marbling score & 217 & $4.92 \pm 78$ & 304 & $4.89 \pm 68$ & 91 & $4.86 \pm 67$ \\
\hline $\mathrm{REA}, \mathrm{cm}^{2}$ & 217 & $77.3 \pm 9.9$ & 303 & $77.9 \pm 10.6$ & 91 & $80.5 \pm 9.9$ \\
\hline $\mathrm{KPH}$ fat, $\%$ & 217 & $2.7 \pm 0.7$ & 304 & $2.8 \pm 0.7$ & 91 & $2.7 \pm 0.6$ \\
\hline Retail product, $\mathrm{kg}$ & 203 & $204 \pm 26$ & 294 & $207 \pm 30$ & 88 & $216 \pm 24$ \\
\hline Retail product, $\%$ & 203 & $66.1 \pm 5.3$ & 294 & $66.2 \pm 5.3$ & 88 & $67.2 \pm 4.5$ \\
\hline Fat trim wt, kg & 203 & $57.6 \pm 21.9$ & 294 & $58.3 \pm 21.2$ & 88 & $55.4 \pm 19.0$ \\
\hline Fat trim, $\%$ & 203 & $18.4 \pm 6.2$ & 294 & $18.5 \pm 6.1$ & 88 & $17.0 \pm 5.2$ \\
\hline Fat in ribs, $\%$ & 204 & $32.8 \pm 7.7$ & 295 & $33.4 \pm 7.9$ & 88 & $32.1 \pm 6.3$ \\
\hline Fat in LM palat, $\%$ & 204 & $3.8 \pm 1.4$ & 296 & $3.6 \pm 1.1$ & 88 & $3.8 \pm 1.4$ \\
\hline Bone wt, kg & 204 & $47.9 \pm 6.3$ & 296 & $47.8 \pm 6.8$ & 88 & $50.5 \pm 6.6$ \\
\hline Bone, $\%$ & 203 & $15.5 \pm 1.5$ & 294 & $15.3 \pm 1.4$ & 88 & $15.7 \pm 1.5$ \\
\hline Shear force, kg & 204 & $5.2 \pm 1.4$ & 296 & $5.2 \pm 1.3$ & 88 & $5.3 \pm 1.4$ \\
\hline Tenderness score & 204 & $5.1 \pm 0.8$ & 296 & $5.1 \pm 0.7$ & 88 & $4.8 \pm 0.8$ \\
\hline Juiciness score & 204 & $5.2 \pm 0.5$ & 296 & $5.2 \pm 0.4$ & 88 & $5.1 \pm 0.5$ \\
\hline Flavor score & 204 & $4.9 \pm 0.4$ & 296 & $4.9 \pm 0.4$ & 88 & $5.0 \pm 0.4$ \\
\hline
\end{tabular}

${ }^{1} \mathrm{EARLY}=\mathrm{d} 1$ to $40 ; \mathrm{MID}=\mathrm{d} 41$ to $80 ;$ LATE $=\mathrm{d} 81$ to slaughter.

${ }^{2}$ Adjusted carcass fat $=$ fat depth at 12 th rib; marbling score, 4.0 to $4.9=$ slight and 5.0 to $5.9=$ small; $\mathrm{REA}=\mathrm{LM}$ area; $\mathrm{KPH}$ fat $=$ estimated $\mathrm{KPH}$; retail product $=$ trimmed steaks and roasts; fat in ribs = chemical fat from soft tissue of 9th to 11th rib cut; fat in LM palat = chemical fat in muscle; shear force = Warner-Bratzler force required to cut through a 1.27-cm core of LM; tenderness score, $4=$ slightly tough, $5=$ slightly tender, and $8=$ extremely tender; juiciness score, $4=$ slightly dry, $5=$ slightly juicy, and $8=$ extremely juicy; flavor score, $4=$ slightly bland, $5=$ slightly intense, and $8=$ extremely intense. 
Table 4. Solutions for bovine respiratory disease-treated calves deviated from healthy calves and $t$-values for significant contrasts for growth and carcass traits

\begin{tabular}{lcc}
\hline \hline Trait $^{2}$ & Solution & $t$-value \\
\hline HCW, kg & -5.64 & 3.67 \\
Adjusted carcass fat, cm & -0.04 & 2.34 \\
REA, cm & 2 & 2.34 \\
KPH fat, \% & -0.96 & 2.13 \\
Retail product, kg & -0.07 & 2.13 \\
Retail product, \% & -2.48 & 1.96 \\
Fat trim wt, kg & -0.33 & 3.04 \\
Fat trim, \% & -2.39 & 2.51 \\
Bone, \% & -0.40 & 3.25 \\
\hline
\end{tabular}

${ }^{1} t$-values greater than 1.96 are significant $(P \leq 0.05)$; values greater than 2.58 are highly significant $(P \leq 0.01)$.

${ }^{2} \mathrm{REA}=\mathrm{LM}$ area.

$28 \mathrm{~d}$ but that this difference decreased to $0.06 \mathrm{~kg}$ after 135 to $238 \mathrm{~d}$ on feed. Because the greatest incidence of BRD generally occurs early in the feedlot, prompt detection and proper treatment would contribute to recovery and subsequent compensatory gain.

No significant contrasts among period-when-treatedfor-BRD groups were detected (data not shown), suggesting animal responses to BRD were similar without respect to when the animal was classified as sick. Although recovery time is highly variable and dependent on numerous factors, cattle properly and promptly treated for BRD with antibiotics and antiinflammatory drugs generally recover in 5 to $6 \mathrm{~d}$. This short period with BRD would have a minor effect on ADG, especially if BRD occurred soon after placement in the feedlot.

When BRD-treated groups were each contrasted with the HEALTHY group (Table 5), the difference in solutions for EARLY and MID groups were significant for some traits. Carcass weight, carcass fat, and area of LM were decreased, and percentage of carcass bone was increased $(P<0.05)$ for the EARLY group compared with the HEALTHY group. Contrasts between MID and

Table 5. Significant contrasts (solutions, $t$-values) among groups for period when treated for bovine respiratory disease for growth and carcass traits ${ }^{1}$

\begin{tabular}{ll}
\hline \hline Trait $^{2}$ & \multicolumn{1}{c}{ Contrasts } \\
\hline HCW, kg & HE $(-7.25,3.30) \mathrm{HM}(-5.26,2.68)$ \\
Adjusted carcass fat, cm & HE $(-0.03,2.40)$ \\
REA, cm ${ }^{2}$ & HE $(-1.47,2.40)$ \\
KPH fat, \% & HM $(-0.11,2.49)$ \\
Retail product, kg & HM $(-1.11,2.49)$ \\
Retail product, \% & HM $(-0.59,2.78)$ \\
Fat trim wt, kg & HM $(-3.41,3.41)$ \\
Fat trim, \% & HM $(-0.72,3.04)$ \\
Bone, \% & HE $(0.19,2.28) \mathrm{HM}(0.20,2.60)$ \\
\hline
\end{tabular}

${ }^{1} t$-values greater than 1.96 are significant $(P \leq 0.05)$; values greater than 2.58 are highly significant $(P \leq 0.01)$. HE $=$ HEALTHY vs. EARLY; HM = HEALTHY vs. MID; solutions for EARLY and MID were deviated from HEALTHY.

${ }^{2} \mathrm{REA}=\mathrm{LM}$ area.
HEALTHY groups indicated that BRD during the MID period decreased carcass weight, percentage KPH fat, and weight and percentage of fat trim $(P<0.05)$. More important was the significant decrease in weight and percentage of retail product associated with the MID group compared with the HEALTHY group.

Estimates of variance components and heritabilities were similar for the univariate and bivariate models. Estimates from the univariate models are reported in Table 6 . The heritability estimate for $\operatorname{BRD}(0.08 \pm 0.01)$ agrees with a previous estimate by Snowder et al. (2006). Heritability estimates for carcass traits were moderate to high, ranging from 0.26 to 0.68 . Estimates for LM palatability traits were moderate, ranging from 0.23 to 0.31 . Estimates for ADG, carcass, and LM palatability traits were in close agreement with previous estimates (Gregory et al., 1995), except for retail product weight and percentage and bone weight. These exceptions were due to differences in estimates of the additive genetic variances. Means, SD, phenotypic variances for retail product weight and percentage, and bone weight were similar to those reported by Gregory et al. (1995). The statistical model in this study included the fixed effect for period-when-treated-for-BRD groups, which was not considered by Gregory et al. (1995). Consequently, the additive genetic variances for retail product weight and percentage and bone weight were larger than the variance estimates from Gregory et al. (1995). The larger additive genetic variances resulted in heritability estimates greater than those reported by Gregory et al. (1995) for retail product weight and percentage ( 0.54 vs. 0.28 and 0.63 vs. 0.47 , respectively) and bone weight ( 0.68 vs. 0.39 ). Of related interest are the significant contrasts between HEALTHY and period-when-treated-for-BRD groups for retail product weight and percentage and bone weight (Table 5). The difference between these 2 studies suggests that health status can be considered as having a significant effect on some traits.

Estimates of phenotypic and genetic correlations among growth, carcass, and LM palatability traits have been previously reported (Gregory et al., 1995; Wheeler et al., 2001). Correlations of BRD with ADG, carcass, and LM palatability traits were usually low or near zero (Table 7). Moderate correlations with BRD were estimated for $\mathrm{HCW}$, retail cuts weight, and bone weight. Phenotypic correlations with BRD ranged from -0.35 to 0.40 . Hot carcass weight, weight of retail cuts, and percentage of carcass bone were moderately correlated phenotypically with $\mathrm{BRD}(0.37,0.40$, and -0.35 , respectively).

Estimates of genetic correlations for ADG, carcass, and LM palatability traits with BRD ranged from -0.42 to 0.20 . Most estimates of genetic correlations had large $\mathrm{SE}$ and were not significantly different from zero. However, the moderate estimates suggest that selection for resistance to BRD may have an undesirable correlated effect on shear force and a reduction in the percentage of bone weight. The small and nonsignificant estimates 
Table 6. Estimates of variance components and heritability $( \pm \mathrm{SE})$ for bovine respiratory disease (BRD), growth, carcass, and LM palatability traits of feedlot cattle ${ }^{1}$

\begin{tabular}{lcccc}
\hline \hline Trait $^{2}$ & $\sigma_{\mathrm{p}}^{2}$ & $\sigma_{\mathrm{a}}^{2}$ & $\sigma_{\mathrm{e}}^{2}$ & $\mathrm{~h}^{2}$ \\
\hline BRD, \% & 1,246 & 93 & 1,128 & $0.08 \pm 0.01$ \\
$\mathrm{ADG}, \mathrm{kg}$ & 21.64 & 7.54 & 14.10 & $0.35 \pm 0.02$ \\
HCW, kg & 884 & 388 & 496 & $0.44 \pm 0.08$ \\
Adjusted carcass fat, cm & 10.07 & 3.07 & 7.00 & $0.31 \pm 0.15$ \\
Marbling score & 0.36 & 0.17 & 0.19 & $0.47 \pm 0.08$ \\
REA, cm & 67.51 & 20.02 & 47.49 & $0.30 \pm 0.07$ \\
KPH fat, \% & 0.38 & 0.10 & 0.28 & $0.26 \pm 0.07$ \\
Retail product, kg & 358.54 & 194.84 & 163.70 & $0.54 \pm 0.08$ \\
Retail product, \% & 10.50 & 6.60 & 3.90 & $0.63 \pm 0.09$ \\
Fat trim, kg & 217.20 & 98.22 & 118.98 & $0.45 \pm 0.08$ \\
Fat trim, \% & 14.05 & 6.91 & 7.14 & $0.49 \pm 0.08$ \\
Fat in ribs, \% & 26.43 & 10.32 & 16.11 & $0.39 \pm 0.08$ \\
Fat in LM, \% & 1.24 & 0.51 & 0.73 & $0.41 \pm 0.08$ \\
Bone wt, kg & 20.73 & 14.08 & 6.65 & $0.68 \pm 0.09$ \\
Bone, \% & 1.10 & 0.31 & 0.79 & $0.28 \pm 0.07$ \\
Shear force, kg & 1.26 & 0.32 & 0.94 & $0.25 \pm 0.07$ \\
Tenderness score & 0.43 & 0.14 & 0.29 & $0.31 \pm 0.07$ \\
Juiciness score & 0.20 & 0.05 & 0.15 & $0.23 \pm 0.07$ \\
\hline
\end{tabular}

${ }^{1} \sigma_{\mathrm{p}}^{2}=$ phenotypic variance; $\sigma_{\mathrm{a}}^{2}=$ additive genetic variance; $\sigma_{\mathrm{e}}^{2}=$ environmental variance; $\mathrm{h}^{2}=$ heritability. ${ }^{2}$ Adjusted carcass fat $=$ fat depth at $12 \mathrm{th}$ rib; marbling score, 4.0 to $4.9=$ slight and 5.0 to $5.9=$ small; $\mathrm{REA}=\mathrm{LM}$ area; $\mathrm{KPH}$ fat $=$ estimated $\mathrm{KPH}$; retail product $=$ trimmed steaks and roasts; fat in ribs = chemical fat from soft tissue of 9th to 11th rib cut; fat in LM = chemical fat in muscle; shear force = WarnerBratzler force required to cut through a 1.27 -cm core of LM; tenderness score, $4=$ slightly tough, $5=$ slightly tender, and $8=$ extremely tender; juiciness score, $4=$ slightly dry, $5=$ slightly juicy, and $8=$ extremely juicy.

Table 7. Estimates of phenotypic, genetic, and environmental correlations of bovine respiratory disease with growth, carcass, and LM palatability traits ${ }^{1}$

\begin{tabular}{lrrr}
\hline Trait $^{2}$ & \multicolumn{1}{c}{$\mathrm{r}_{\mathrm{P}}$} & \multicolumn{1}{c}{$\mathrm{r}_{\mathrm{A}}$} & \multicolumn{1}{c}{$\mathrm{r}_{\mathrm{E}}$} \\
\hline ADG & 0.11 & $0.08 \pm 0.07$ & $0.12 \pm 0.01$ \\
HCW, kg & 0.37 & $0.04 \pm 0.14$ & $0.48 \pm 0.04$ \\
Adjusted carcass fat, cm & 0.04 & $-0.08 \pm 0.15$ & $0.07 \pm 0.04$ \\
Marbling score & 0.02 & $0.09 \pm 0.13$ & $0.00 \pm 0.04$ \\
REA, cm & 0.02 & $-0.12 \pm 0.15$ & $0.06 \pm 0.03$ \\
KPH fat, \% & 0.27 & $0.19 \pm 0.16$ & $0.29 \pm 0.04$ \\
Retail product, kg & 0.40 & $0.04 \pm 0.13$ & $0.55 \pm 0.05$ \\
Retail product, \% & 0.04 & $-0.12 \pm 0.13$ & $0.11 \pm 0.04$ \\
Fat trim, kg & 0.07 & $0.07 \pm 0.13$ & $0.08 \pm 0.04$ \\
Fat trim, \% & 0.12 & $0.14 \pm 0.13$ & $0.14 \pm 0.06$ \\
Fat in ribs, \% & -0.12 & $-0.03 \pm 0.14$ & $-0.16 \pm 0.06$ \\
Fat in LM, \% & 0.19 & $0.09 \pm 0.14$ & $0.23 \pm 0.05$ \\
Bone wt, kg & -0.22 & $-0.19 \pm 0.12$ & $0.32 \pm 0.07$ \\
Bone, \% & -0.35 & $-0.42 \pm 0.14$ & $-0.36 \pm 0.04$ \\
Shear force, kg & 0.00 & $0.20 \pm 0.16$ & $-0.04 \pm 0.03$ \\
Tenderness score & 0.01 & $-0.16 \pm 0.15$ & $0.01 \pm 0.03$ \\
Juiciness score & 0.00 & $0.09 \pm 0.17$ & $-0.02 \pm 0.03$ \\
\hline
\end{tabular}

${ }^{1} \mathrm{r}_{\mathrm{P}}=$ phenotypic correlation; $\mathrm{r}_{\mathrm{A}}=$ genetic correlation; $\mathrm{r}_{\mathrm{E}}=$ environmental correlation.

${ }^{2}$ Adjusted carcass fat $=$ fat depth at 12 th rib; marbling score, 4.0 to 4.9 = slight and 5.0 to $5.9=$ small; $\mathrm{REA}=\mathrm{LM}$ area; $\mathrm{KPH}$ fat $=$ estimated $\mathrm{KPH}$; retail product $=$ trimmed steaks and roasts; fat in ribs $=$ chemical fat from soft tissue of 9th to 11th rib cut; fat in LM = chemical fat in muscle; shear force $=$ Warner-Bratzler force required to cut through a 1.27-cm core of LM; tenderness score, $4=$ slightly tough, $5=$ slightly tender, and $8=$ extremely tender; juiciness score, $4=$ slightly dry, $5=$ slightly juicy, and $8=$ extremely juicy. of genetic correlations suggest that selection to reduce BRD in feedlot cattle would have negligible effects on growth, carcass, and LM palatability traits. Perhaps, most importantly, selection to reduce BRD would have minor economic consequences on production traits or product quality.

Estimates of environmental correlations of the traits with BRD had much smaller SE and were also generally low or near zero. However, environmental approaches, including management and preventative therapies to decrease BRD incidence, will increase $\mathrm{HCW}$ and weight of retail cuts and will decrease percentage of bone weight. For example, preconditioning treatment of feedlot cattle has a significant effect on reducing the number of calves treated for BRD (Roeber et al., 2001).

\section{LITERATURE CITED}

Bateman, K. G., W. Martin, P. E. Shewen, and P. I. Menzies. 1990. An evaluation of antimicrobial therapy for undifferentiated bovine respiratory disease. Can. Vet. J. 31:689-696.

Boldman, K. G., L. A. Kriese, L. D. Van Vleck, C. P. Van Tassell, and S. D. Kachman. 1995. A manual for use of MTDFREML. A set of programs to obtain estimates of variances and covariances. USDA, ARS, Clay Center, NE.

Brandsma, J. H., L. L. G. Janss, and A. H. Visser. 2004. Association between PrP genotypes and littersize and 135 days weight in Texel sheep. Livest. Prod. Sci. 85:59-64.

Dodenhoff, J., L. D. Van Vleck, S. D. Kachman, and R. M. Koch. 1998. Parameter estimates for direct, maternal and grandmaternal genetic effects for birth weight and weaning weight in Hereford cattle. J. Anim. Sci. 76:2521-2527.

Faber, R., N. Hartwig, D. Busby, and R. BreDahl. 1999. The costs and predictive factors of bovine respiratory disease in standardized 
steer tests. AS Leaflet R1648. 1999 Beef Res. Rep. Iowa State Univ. Press, Ames.

Falconer, D. S. 1976. Introduction to Quantitative Genetics. Ronald Press Co., New York, NY.

Gardner, B. A., H. G. Dolezal, L. K. Bryant, F. N. Owens, and R. A. Smith. 1999. Health of finishing steers: Effects on performance, carcass traits, and meat tenderness. J. Anim. Sci. 77:3168-3175.

Graser, H. U., S. P. Smith, and B. Tier. 1987. A derivative-free approach for estimating variance components in animal models by restricted maximum likelihood. J. Anim. Sci. 64:1362-1370.

Gregory, K. E., L. V. Cundiff, and R. M. Koch. 1991. Breed effects and heterosis in advanced generations of composite populations for preweaning traits of beef cattle. J. Anim. Sci. 69:947-960.

Gregory, K. E., L. V. Cundiff, and R. M. Koch. 1994a. Breed effects, dietary energy density effects, and retained heterosis on different measures of gain efficiency in beef cattle. J. Anim. Sci. 72:1138-1154.

Gregory, K. E., L. V. Cundiff, and R. M. Koch. 1995. Genetic and phenotypic (co)variances for growth and carcass traits of purebred and composite populations of beef cattle. J. Anim. Sci. 73:1920-1926.

Gregory, K. E., L. V. Cundiff, R. M. Koch, M. E. Dikeman, and M. Koohmaraie. 1994b. Breed effects and retained heterosis for growth, carcass, and meat traits in advanced generations of composite populations of beef cattle. J. Anim. Sci. 72:833-850.

Gregory, K. E., L. V. Cundiff, R. M. Koch, M. E. Dikeman, and M. Koohmaraie. 1994c. Breed effects, retained heterosis, and estimates of genetic and phenotypic parameters for carcass and meat traits of beef cattle. J. Anim. Sci. 72:1174-1183.

Griffin, D. 1997. Economic impact associated with respiratory disease in beef cattle. Vet. Clin. North Am. Food Anim. Pract. 3:367-377.

Isler, B. J., B. A. Freking, R. M. Thallman, M. P. Heaton, and K. A. Leymaster. 2006. Evaluation of associations between prion haplotypes and growth, carcass, and meat quality traits in a Dorset $\times$ Romanov sheep population. J. Anim. Sci. 84:783-788.

Jim, G. K., C. W. Booker, C. S. Ribble, P. T. Guichon, and B. E. Thorlakson. 1993. A field investigation of the economic impact of respiratory disease in feedlot calves. Can. Vet. J. 34:668-673.

Leenstra, F. 1993. Selection for disease resistance in poultry: General or specific? Arch. Geflügelk. 57:69-73.

Miller, L. L., P. B. Spiegel, and E. A. Dunnington. 1992. Inheritance of antibody response to sheep erythrocytes in lines of chickens divergently selected for 56-day body weight and their crosses. Poult. Sci. 71:47-52.

Nestor, K. E., D. O. Noble, J. Zhu, and Y. Moritsu. 1996. Direct and correlated responses to long-term selection for increased body weight and egg production in turkeys. Poult. Sci. 75:1180-1191.

Pollott, G. E., and J. C. Greef. 2004. Genotype × environment interactions and genetic parameters for fecal egg count and production traits of Merino sheep. J. Anim. Sci. 82:2840-2851.

Rauw, W. M., E. Kanis, E. N. Noordhuizen-Stassen, and F. J. Grommers. 1998. Undesirable side effects of selection for high production efficiency in farm animals: A review. Livest. Prod. Sci. $56: 15-33$.

Rios-Utrera, A., L. V. Cundiff, K. E. Gregory, R. M. Koch, M. E. Dikeman, M. Koohmaraie, and L. D. Van Vleck. 2005. Genetic analysis of carcass traits of steers adjusted to age, weight, or fat thickness slaughter end points. J. Anim. Sci. 83:764-776.

Roeber, D. L., N. C. Speer, J. G. Gentry, J. D. Tatum, C. D. Smith, J. C. Whittier, G. F. Jones, K. E. Belk, and G. C. Smith. 2001. Feeder cattle health management: Effects on morbidity rates, feedlot performance, carcass characteristics, and beef palatability. Prof. Anim. Sci. 17:39-44.

Sather, A. P. 1987. A note on the changes in leg weakness in pigs after being transferred from confinement housing to pasture lots. Anim. Prod. 44:450-453.

Simianer, H., H. Solbu, and L. R. Schaeffer. 1991. Estimated genetic correlations between disease and yield traits in dairy cattle. J. Dairy Sci. 74:4358-4365.

Snowder, G. D., L. D. Van Vleck, L. V. Cundiff, and G. L. Bennett. 2006. Bovine respiratory disease in feedlot cattle: Environmental, genetic and economic factors. J. Anim. Sci. 84:1999-2008.

Van Dorp, T. E., J. C. M. Dekkers, S. W. Martin, and J. P. T. M. Noordhuizen. 1998. Genetic parameters of health disorders and relationships with 305-day milk yield and conformation traits of registered Holstein cows. J. Dairy Sci. 81:2264-2270.

Wheeler, T. L., L. V. Cundiff, S. D. Shackelford, and M. Koohmaraie. 2001. Characterization of biological types of cattle (Cycle V): Carcass traits and longissimus palatability. J. Anim. Sci. 79:1209-1222.

Wittum, T. E., N. E. Woollen, L. J. Perino, and E. T. Littledike. 1996. Relationships among treatment for respiratory tract disease, pulmonary lesions evident at slaughter, and rate of weight gain in feedlot cattle. J. Am. Vet. Med. Assoc. 209:814-818. 